\title{
Presence of Gingival Recession or Noncarious Cervical Lesions on Teeth under Occlusal Trauma: A Systematic Review
}

\author{
Pedro Maria Bastião Peliz Senos Tróia ${ }^{1}$ Tobias Rauber Spuldaro ${ }^{1}$ Patrícia Alexandra Barroso da Fonseca ${ }^{2}$ \\ Gustavo Vicentis de Oliveira Fernandes ${ }^{2, \odot}$
}

${ }^{1}$ Faculty of Dental Medicine, Universidade Católica Portuguesa, Viseu, Portugal

${ }^{2}$ Centre for Interdisciplinary Research in Health (CIIS), Department of Dental Medicine, Universidade Católica Portuguesa, Viseu, Portugal

\begin{abstract}
Address for correspondence Gustavo Vicentis de Oliveira Fernandes, PhD, Quinta da Alagoa Ave., 225 - 1 DT, Viseu, 3500-606, Portugal (e-mail: gustfernandes@gmail.com).
\end{abstract}

Eur J Gen Dent 2021;10:50-59.

\begin{abstract}
The goal of this research was to carry out a systematic review to verify the possible influence of occlusal factors on the occurrence of gingival recession and noncarious cervical lesions. To answer the specific research question-whether gingival recession or noncarious cervical lesions on teeth are present under occlusal trauma-a bibliographic search was conducted at MEDLINE/PubMed, Web of Science, and Gray Literature databases focusing on articles published, following strict inclusion criteria based on randomized clinical trials, controlled clinical studies, and case series, with restricted language (English) and publication date between March 2010 and March 2020, considering patients with occlusal trauma and gingival recession/noncarious cervical injuries. Questionnaires, animal or laboratory studies, case reports, and interviews were excluded. First, the title and/or abstract of the articles obtained were analyzed and, finally, a full-text reading was performed. Given the amount and diversity of the final studies, a qualitative analysis was made. Based on the established

Keywords

- dental occlusion

- gingival recessions

- noncarious cervical lesions

- occlusal trauma

- systematic review criteria, it was possible to obtain an initial 757 articles. After screening, five articles were included, and then qualitative analysis was performed. The results described in the articles were different, given the heterogeneity of the articles subjected to analysis. A few studies were published in the past 10 years, suggesting that the traumatic occlusion seems to be associated with the occurrence of the noncarious cervical lesion while it is not possible to arrive at a conclusion with regard to the association of gingival recession and occlusal trauma.
\end{abstract}

Key Message: Even though many professionals have categorically affirmed that there is a relation between trauma occlusal and gingival recession/noncarious cervical lesion, this systematic review found the absence of strong literature to really prove it. Once defined, it allows the therapeutic focus to centre on the causal or contributing factors and preventing or reducing future recurrence.
DOI https://doi.org/

$10.1055 / \mathrm{s}-0041-1732781$

ISSN 2320-4753 (c) 2021. European Journal of General Dentistry.

This is an open access article published by Thieme under the terms of the Creative Commons Attribution-NonDerivative-NonCommercial-License, permitting copying and reproduction so long as the original work is given appropriate credit. Contents may not be used for commercial purposes, or adapted, remixed, transformed or built upon. (https://creativecommons.org/licenses/by-nc-nd/4.0/).

Thieme Medical and Scientific Publishers Pvt. Ltd. A-12, 2nd Floor, Sector 2, Noida-201301 UP, India 


\section{Introduction}

Gingival recession (GR) is defined as the migration of the marginal gingiva to an apical level, using as reference the cementoenamel junction (CEJ), exposing the root surface and involving loss of periodontal attachment apparatus. ${ }^{1,2}$ Multiple factors can be involved causing or aggravating the $\mathrm{GR}^{2,3}$ which can be divided into three groups: anatomical factors (dehiscence of the alveolar bone and abnormal position of the teeth), physiological factors (orthodontic movements), and pathological factors (abrasive and traumatic brushing, intra- and perioral piercing, tooth mobility, partial denture, deficient dental restorations [mainly with subgingival margins], bacterial plaque, periodontal diseases, damages resulting from iatrogenesis and use of tobacco [smoking], and occlusal trauma) $)^{4-9}$

Occlusal trauma is characterized as an excessive masticatory force with varying intensities, present in premature contacts or interferences, that exceeds the adaptive and reparative physiological capacity of the periodontal resistance. ${ }^{10,11}$ Consequently, bone resorption may occur, normally, in the tooth's cervical region ${ }^{10}$ due to forces that are concentrated in a few points of the tooth, ${ }^{12,13}$ characterizing a pathological occlusion. ${ }^{14-16}$

Hence, occlusal disturb may increase inflammation of the periodontal structures and destruction of the collagen matrix, enhancing the osteoclasts activities, ${ }^{17}$ and causing GRs, ${ }^{6,10}$ which may cause greater susceptibility to the occurrence of root caries and root abrasion, jeopardizing esthetic, dentin hypersensitivity, reduction of keratinized tissue, and disharmony of the gingival margin. ${ }^{5,7}$ However, it should also be noted that the occurrence of a traumatic occlusal force depends on factors such as magnitude, direction, duration, and frequency. ${ }^{18}$ Therefore, the relation between GR and occlusal trauma needs to be clarified.

Another factor related to occlusal trauma is the presence of noncarious cervical lesions (NCCLs). Abrasion (abnormal frictional biomechanical process), erosion (mainly due to acidic dissolution), and abfraction (pathological loss of dental hard tissues due to biomechanical occlusal forces) $)^{19,20}$ zwas suggested, based in a little evidence existent, as a hypothetical component of cervical wear and could also be associated with periodontal disease. ${ }^{21}$ A study of NCCL pointed to abrasive toothpaste and traumatic brushing as the main causes of their occurrence. ${ }^{22}$ However, Lee and Eakle ${ }^{23}$ proposed that the occlusal forces with relevant cervical stress, resulting in the breaking of the enamel hydroxyapatite bonds and the consequent microfracture, chipping, and loss of structure, ${ }^{24}$ could play a major role in the NCCL etiology.

Since it was suggested, several laboratory studies of finite elements and in vivo have emerged. Bernhardt et a ${ }^{25}$ considered that this association exists, although other clinical researches ${ }^{26,27}$ studied individuals with a parafunctional habit of bruxism who had an even greater number of NCCL than subjects without any habit. Thereby, occlusal adjustments to eliminate interferences have not decreased the progression of NCCL. ${ }^{22}$ Furthermore, in a 3-year follow-up study, ${ }^{28}$ it was suggested that the facets consequent of occlusal wear was associated with a higher incidence of NCCL. Although the NCCL etiology is currently supported by the biomechanical concept of distribution of occlusal forces, there is a lack of scientific evidence. ${ }^{5}$ Then, it is wrong to restrict only one mechanism responsible for the occurrence of any NCCL type. ${ }^{29}$

Observing the aforementioned facts, the aim of this systematic review (SR) was identifying the relationship between GR and NCCL on teeth under occlusal trauma, providing a scientific answer for the existent problem.

\section{Material and Methods}

This SR was conducted following the Preferred Reporting Items for Systematic Reviews and Meta-Analysis guidelines. ${ }^{30}$ The protocol for this study was registered on PROSPERO (CRD42020183268). The focused question for the present review was as follows: "Is there a relation between the presence of occlusal trauma and the appearance of GRs or noncarious abfraction lesions?"

\section{Information Sources and Search Strategy}

A bibliographic search was conducted using MEDLINE/ PubMed, Web of Science, and Gray Literature databases (http://opengrey.eu, http://greylit.org, http://greynet.org, https://www.oclc.org/en/oaister.html, and https://rcaap.pt) (Supplementary Table S1), to collect articles published between March 2010 until March 2020 (10 years), with English language restriction.

The used terms were "Non-carious lesions" OR "Noncarious lesions" OR "Cervical lesions" OR "Abfraction" OR "Gingival recession" OR "Gingival retraction" OR "Gum recession" OR "Gum retraction" AND "occlus" * OR "Occlusal trauma" OR "traumatic occlusion" OR "excessive occlusal force" OR "pathologic occlusion" OR "dysfunctional occlusion." The research was performed combining the previous terms (Supplementary Table S1), applying the filters described in Supplementary Table S2. An additional manual search was performed on the references of included articles to identify relevant publications.

\section{Inclusion Criteria}

This study was conducted based on randomized clinical trials, controlled clinical studies, and case series. The mandatory simultaneous criteria used were: clinical studies; studies published in English; publication date from March 2010 to March 2020; human studies; and articles that have the search terms in the title or abstract. Nonsimultaneous criteria were also applied, such as patients with occlusal trauma and GR (with detailed information about the type of GR); patients with occlusal trauma and noncarious cervical injuries (with detailed information about the type of noncarious cervical injury).

\section{Exclusion Criteria}

Clinical studies that did not fully meet the inclusion criteria, studies based on questionnaires, case reports, editorial letters, SRs, and meta-analysis, laboratory and animal studies, and interviews. 


\section{Study Selection and Quality Assessment}

After the bibliographic search, two independent researchers (P.M.B.P.S.T. and T.R.S.) proceeded to filter relevant articles that fitted the study by analyzing the title and abstract for study selection. Any disagreement between the reviewers was discussed with a third author (G.V.O.F.). Cohen's kappa test was performed to assess the reviewers' agreement. Assessment of risk of bias and study quality of the included studies were performed independently by two reviewers (P.M.B.P.S.T. and G.V.O.F.), where the Strengthening the Reporting of Observational Studies in Epidemiology (STROBE) statement was applied. It featured 18 items that were answered with one of four options: 1-yes, 2-no, 3cannot answer, and 4-not applicable. Only items with option 1 generated the score. Therefore, each article could obtain a score between 0 (no criteria fulfilled) and 18 (all criteria fulfilled).

The data collected using the STROBE statement was rated in a total of 18 points, among the 22 topics, as low quality (scored 0-6 out of a total of 18 points), as moderate quality (7-12), or as high quality (13-18). The ratings obtained were verified by a third reviewer (T.R.S.) and any discrepancy was resolved by discussion with another reviewer (P.A.B.F.).

\section{Data Extraction}

Reviewers extracted the data independently from the selected articles for further analysis using data extraction tables, which included the following parameters: author(s), year of publication, study design, main goal, the number of participants, systemic condition, exclusion criteria, and occlusal assessment method. All values and details were reported.

\section{Results}

\section{Study Selection, Characteristics, and}

\section{Description/Quality Assessment and Heterogeneity}

The study selection is described in the flow diagram

( - Fig. 1). A total of 757 articles were obtained, of which 83 were duplicate, thus resulting in 674 final articles from MEDLINE/PubMed $(n=371)$, Web of Science $(n=294)$, and Gray Literature $(n=9)$. After reading the title and abstract of these articles, 19 articles were chosen to be read full text, PubMed $(n=12)$, Web of Science $(n=6)$, and Gray Literature $(n=1)$. Afterward, 14 were excluded with justification described in - Table 1, the remaining 5 articles were chosen for inclusion ( 1 case-control and 4 cross-sectional studies). The agreement value between examiners was respectively 90.61 and $92.4 \%$.

A summary was made about the articles included in this study ( - Table 2 ), containing the journal, the year of publication, the type of study, objective, inserted and excluded patients, and method used for assessing occlusal trauma. However, - Table 3 refers to the detailed results relevant to this study and the conclusions of each article.

A fact that was verified in all five included studies was the detailed description of the occlusal factors and its assessment method. The factors analyzed were different in each study,

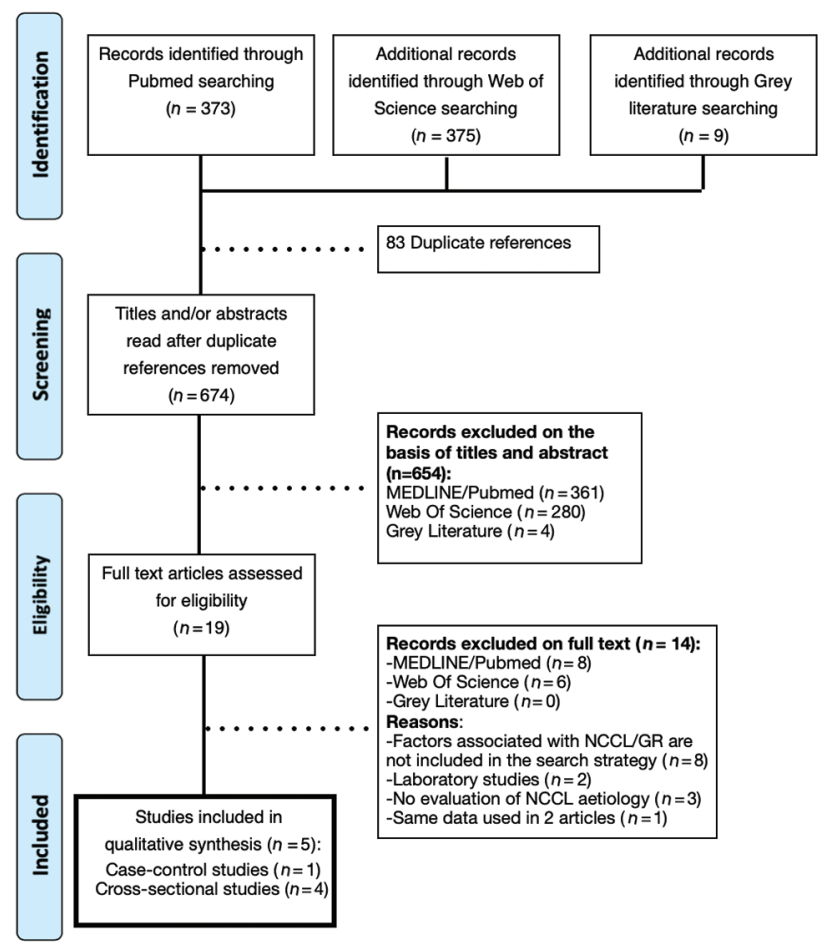

Fig. 1 Articles selection flow diagram based on the Preferred Reporting Items for Systematic Reviews and Meta-Analysis (PRISMA) statement.

integrating the panoply of analyzed factors were the following: prematurity in centric relation and excursive movements, ${ }^{31}$ prematurity at maximum intercuspation and on the nonwork side, ${ }^{32,33}$ guides and occlusal contacts, ${ }^{34}$ and interferences in centric relation, maximum intercuspation, and excursive movements. ${ }^{35}$ The articular-paper used (Accufilm II, Parkell, Edgewood, New York, United States) for evaluation was the same in four of the five articles, ${ }^{31-33,35}$ contrasting with the only study ${ }^{34}$ in which it was used a distinct type of articular-paper (Bausch Arti-Check, Bausch Articulating Papersn Inc., Nashua, New Hampshire, United States).

Four articles ${ }^{31,32,34,35}$ described the method used in the NCCL and GR diagnosis although heterogeneity has been observed, and only one article ${ }^{33}$ did not describe the method applied. Teixeira et al, ${ }^{31}$ Yoshizaki et al, ${ }^{32}$ and Brandini et $\mathrm{al}^{35}$ developed all analyses with only one examiner, while in Alvarez-Arenal et al study, ${ }^{34}$ six researchers (one of each university included) performed the diagnosis. It is also worth mentioning that Smith and Knight Dental Wear Classification ${ }^{36}$ were used to classify NCCL.

Teixeira et al $^{31}$ classified the lesions according to their morphology (concave or wedge shapes) and the depth (superficial: 0-0.9 mm, medium: 1.0-1.9 mm, deep: $>2.0 \mathrm{~mm}$ ), for which, impressions with an elastomeric material was used and, for GRs, Miller's classification was applied. Yoshizaki et $\mathrm{al}^{32}$ and Brandini et $\mathrm{a}^{35}$ studies described that any discrepancy resulting from tooth structure loss at the level of the CEJ, not resulting from caries, was considered as NCCL. Despite these similarities, it is important to note that a classification regarding the lesions form was performed by Yoshizaki et al. ${ }^{32}$ 
Table 1 Articles excluded from the study, authors, and the reason for exclusion

\begin{tabular}{|c|c|c|}
\hline Title & Authors & Exclusion motive \\
\hline $\begin{array}{l}\text { Secondary trauma from occlusion and } \\
\text { periodontitis }\end{array}$ & $\begin{array}{l}\text { Mark Branschofsky, Thomas Bieler, Ralf Schafer, } \\
\text { Thomas F Flemming, Herman Lang }\end{array}$ & $\begin{array}{l}\text { Factors associated with NCCL/GR are not } \\
\text { included in the research strategy }\end{array}$ \\
\hline $\begin{array}{l}\text { Clinical evaluation of the association of } \\
\text { noncarious cervical lesions, parafunc- } \\
\text { tional habits, and TMD diagnosis }\end{array}$ & $\begin{array}{l}\text { Daniela Atili Brandini, Sônia Regina Panzarini, } \\
\text { Igor Mariotto Benete, Carolina Lunardelli Trevisan }\end{array}$ & $\begin{array}{l}\text { Factors associated with NCCL/GR are not } \\
\text { included in the research strategy }\end{array}$ \\
\hline $\begin{array}{l}\text { Factors influencing the progression of } \\
\text { noncarious cervical lesions: A 5-year } \\
\text { prospective clinical evaluation }\end{array}$ & $\begin{array}{l}\text { Kanchan Sawlani, Nathaniel C. Lawson, John O. } \\
\text { Burgess, Jack E. Lemons, Keith E. Kindernecht, } \\
\text { Daniel A. Givan, Lance Ramp }\end{array}$ & $\begin{array}{l}\text { Factors associated with NCCL/GR are not } \\
\text { included in the research strategy }\end{array}$ \\
\hline $\begin{array}{l}\text { Noncarious cervical lesions (NCCLs) in a } \\
\text { random sampling community popula- } \\
\text { tion and the association of NCCLs with } \\
\text { occlusive wear }\end{array}$ & $\begin{array}{l}\text { J. Yang, D. Cai, F. Wang, D. He, L. Ma, Y. Jin, K. } \\
\text { Que }\end{array}$ & $\begin{array}{l}\text { Factors associated with NCCL/GR are not } \\
\text { included in the research strategy }\end{array}$ \\
\hline $\begin{array}{l}\text { The role of occlusal loading in the patho- } \\
\text { genesis of noncarious cervical lesions }\end{array}$ & $\begin{array}{l}\text { John R. Antonelli, Timothy L. Hottel, Robert } \\
\text { Brandt, Mark Scarbecz, Tejas Patel }\end{array}$ & $\begin{array}{l}\text { Factors associated with NCCL/GR are not } \\
\text { included in the research strategy }\end{array}$ \\
\hline $\begin{array}{l}\text { Association of noncarious cervical lesions } \\
\text { with oral hygiene habits and dynamic } \\
\text { occlusal parameters }\end{array}$ & $\begin{array}{l}\text { Satheesh B. Haralur, Abdulrahman Saad } \\
\text { Alqahtani, Mohammed Shaya AlMazni, } \\
\text { Mohammad Khalid Alqahtani }\end{array}$ & $\begin{array}{l}\text { Factors associated with NCCL/GR are not } \\
\text { included in the research strategy }\end{array}$ \\
\hline $\begin{array}{l}\text { New insights in the link between maloc- } \\
\text { clusion and periodontal disease }\end{array}$ & $\begin{array}{l}\text { Olaf Bernhardt, Karl-Fiedrich Krey, Amro Daboul, } \\
\text { Henry Volzke, Stefan Kindler, Thomas Kocher, } \\
\text { Christian Schwahn }\end{array}$ & $\begin{array}{l}\text { Factors associated with NCCL/GR are not } \\
\text { included in the research strategy }\end{array}$ \\
\hline $\begin{array}{l}\text { Relationship between self-reported brux- } \\
\text { ism and periodontal status: Findings from } \\
\text { a cross-sectional study }\end{array}$ & $\begin{array}{l}\text { João Botelho, Vanessa Machado, Luís Proença, } \\
\text { João Rua, Leonardo Martins, Ricardo Alves, Maria } \\
\text { Alzira Cavacas, Daniele Manfredini, José João } \\
\text { Mendes }\end{array}$ & $\begin{array}{l}\text { Factors associated with NCCL/GR are not } \\
\text { included in the research strategy }\end{array}$ \\
\hline $\begin{array}{l}\text { Noncarious cervical lesions: why on the } \\
\text { facial? A theory }\end{array}$ & W. Dan Sneed & No assessment for etiology of NCCL \\
\hline $\begin{array}{l}\text { Erosive tooth wear and wedge-shaped } \\
\text { defects in } 1996 \text { and 2006: cross- sectional } \\
\text { surveys of Swiss army recruits }\end{array}$ & $\begin{array}{l}\text { Adrian Lussi, Matthias Strub, Ernst Schurch, } \\
\text { Markus Schaffner, Walter Burgen, Thomas Jaeggi }\end{array}$ & No assessment for etiology of NCCL \\
\hline $\begin{array}{l}\text { Abfraction, abrasion, biocorrosion, and } \\
\text { the enigma of noncarious cervical lesions: } \\
\text { a } 20 \text {-year perspective }\end{array}$ & $\begin{array}{l}\text { John O. Grippo, Marvin Simring, Thomas A. } \\
\text { Coleman }\end{array}$ & No assessment for etiology of NCCL \\
\hline $\begin{array}{l}\text { Biomechanics of noncarious cervical } \\
\text { lesions }\end{array}$ & G. Beresescu, L.C. Brezeanu & Laboratorial study \\
\hline $\begin{array}{l}\text { Effects of occlusal loads in the genesis } \\
\text { of noncarious cervical lesions - a finite } \\
\text { element study }\end{array}$ & $\begin{array}{l}\text { Andreea Stanusi, Veronica Mercut, Monica } \\
\text { Scrieciu, Mihaela Sanda Popescu, Monica } \\
\text { Mihaela Craitoiu lacob, Luminita Daguci, Stefan } \\
\text { Castravete, Daniela Doina Vintila, Mihaela Vatu }\end{array}$ & Laboratorial study \\
\hline $\begin{array}{l}\text { The role of occlusal factors in the pres- } \\
\text { ence of noncarious cervical lesions in } \\
\text { young people: a case-control study }\end{array}$ & $\begin{array}{l}\text { A. Alvarez-Arenal, L. Alvarez-Menendez, I. } \\
\text { Gonzales-Gonzalez, E. Jiménez-Castellanos, M } \\
\text { Garcia-Gonzalez, H deLlanos-Lanchares }\end{array}$ & $\begin{array}{l}\text { Same data/patients used in two differ- } \\
\text { ent articles }\end{array}$ \\
\hline
\end{tabular}

Abbreviations: GR, gingival recession; NCCL, noncarious cervical lesion; TMD, temporomandibular disorder.

The quality assessment of all studies included was considered high, considering them as low risk of bias ( - Fig. 2 ), with the following results: Teixeira et al, ${ }^{31}$ Alvarez-Arenal et al, ${ }^{34}$ and Brandini et $\mathrm{a}^{35}$ with score of 16 , and Yoshizaki et $\mathrm{a}^{32}$ and Figueiredo et $\mathrm{al}^{33}$ with score of 15.

\section{Participants}

Heterogeneity was observed across all the studies. In three studies, $^{37-39}$ the participants were patients from the services of each institution; in one, ${ }^{40}$ the population was students; and, in the another, ${ }^{41}$ the population was patients, students, and employees of the institution. All studies were conducted in dental clinics at educational institutions (4 in Brazil ${ }^{31-33,35}$ and 1 in Spain ${ }^{34}$ ). Besides, three studies $^{31,32,35}$ detailed the number of teeth analyzed and the age was considered a possible etiological factor by three out of five studies ${ }^{31,32,35}$ which had a reduced average rating between 39 and 41 years, and in two ${ }^{31,35}$ there was a positive association between the increased prevalence of NCCL and age. Only Yoshizaki et $\mathrm{a}^{32}$ found a higher prevalence of NCCL in the group of patients aged 31 to 50 years and not in the group corresponding with more advanced age (> 50 years). Only Teixeira et $\mathrm{al}^{31}$ observed an association between age and GR.

\section{Occlusal Factors and Characteristics}

After analysis of the different occlusal factors was conducted, the report of its influence on the occurrence of the injury was transversal to all the five studies. In two, 32,33 it was found that prematurity at maximum intercuspation and on the nonwork side were factors associated with the occurrence of 


\begin{tabular}{|c|c|c|c|c|c|}
\hline 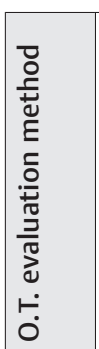 & 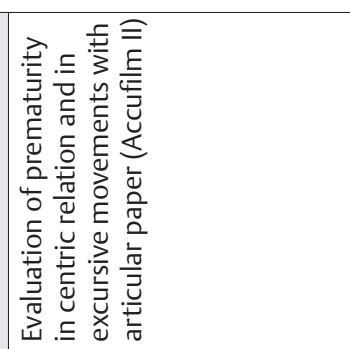 & 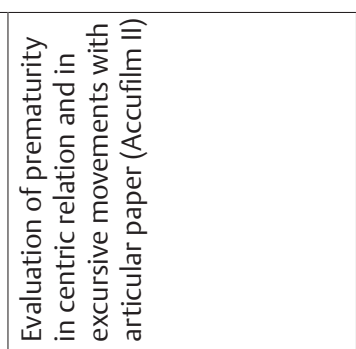 & 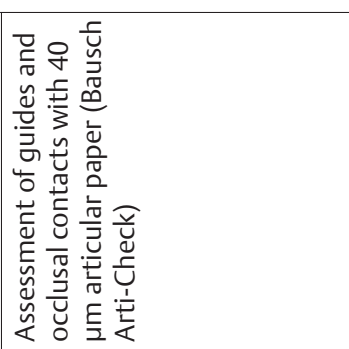 & 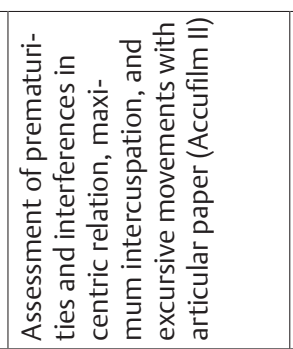 & 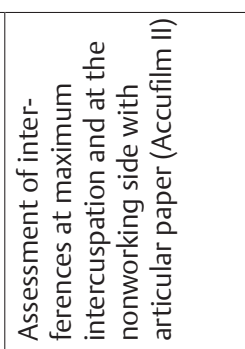 \\
\hline 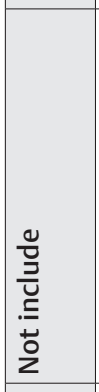 & 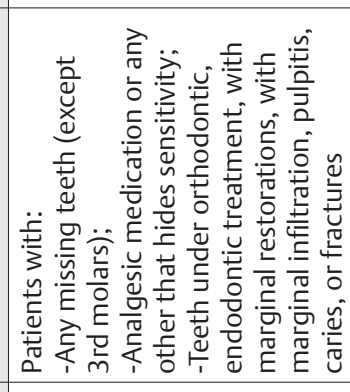 & 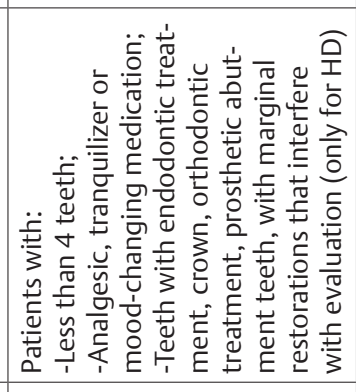 & 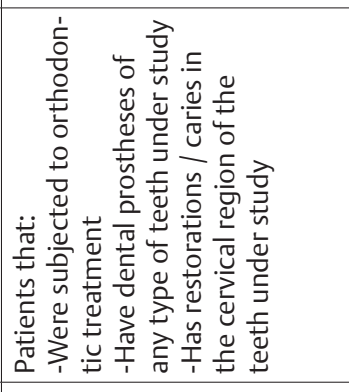 & 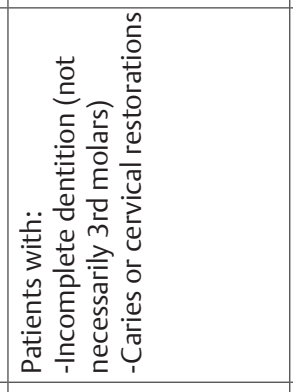 & 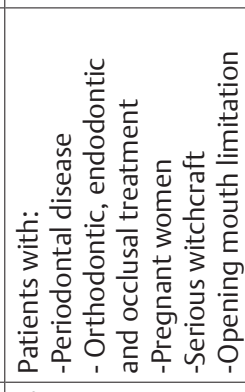 \\
\hline 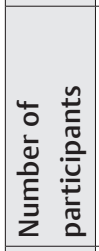 & 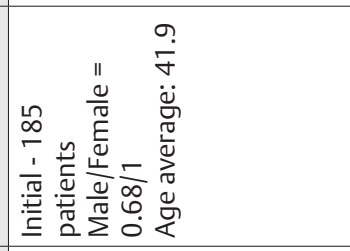 & 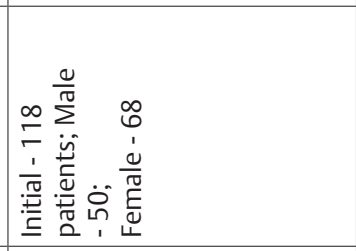 & 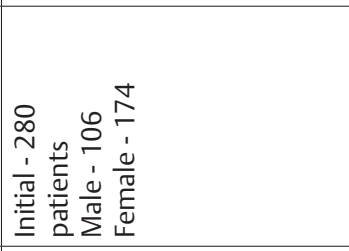 & 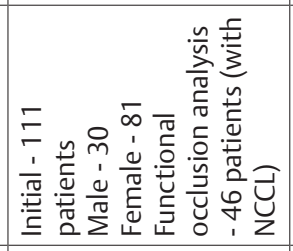 & 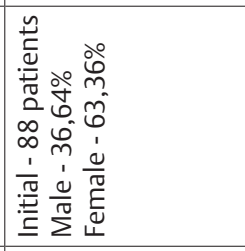 \\
\hline 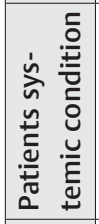 & 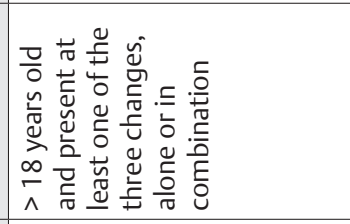 & 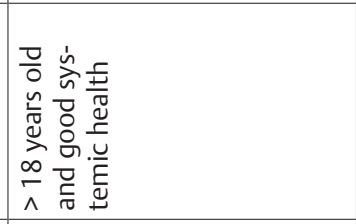 & 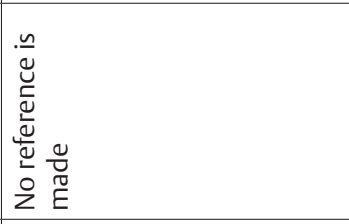 & 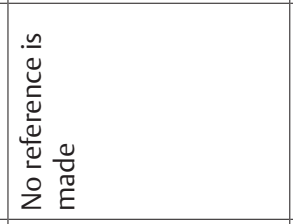 & 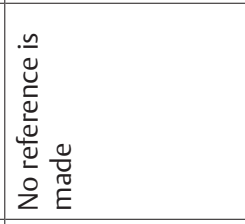 \\
\hline 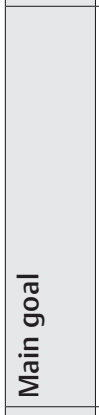 & 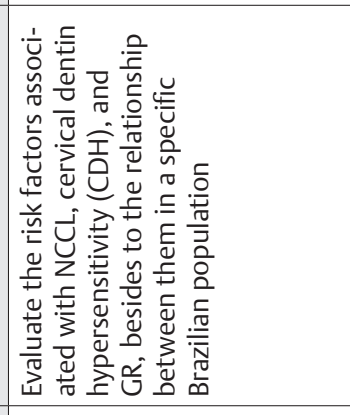 & 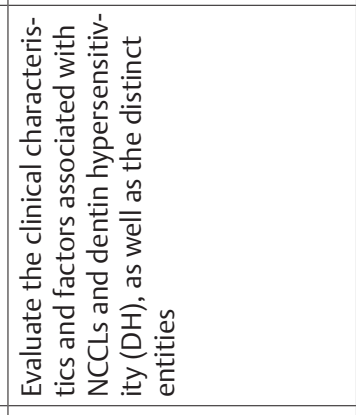 & 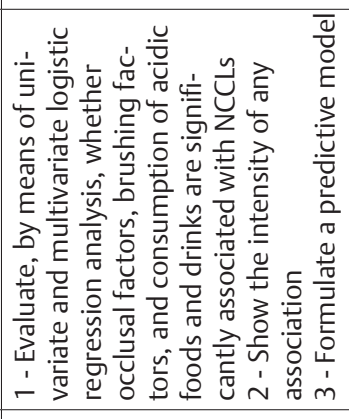 & 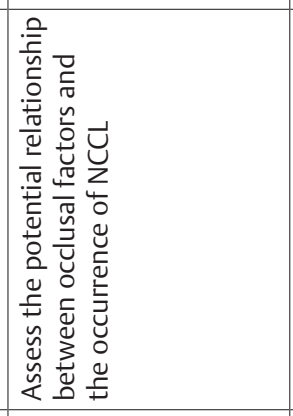 & 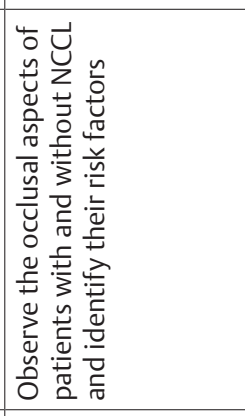 \\
\hline 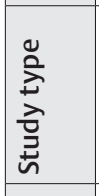 & 离 & 范 & 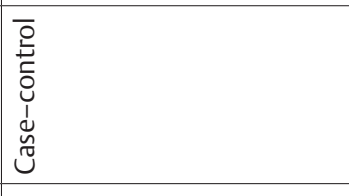 & 离 & 苋 \\
\hline 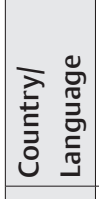 & 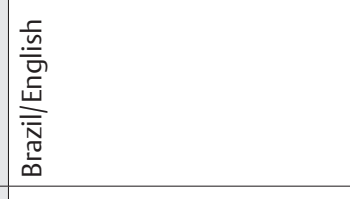 & 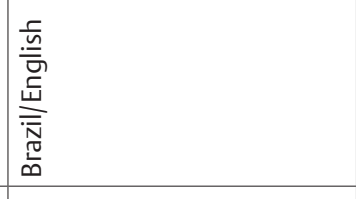 & 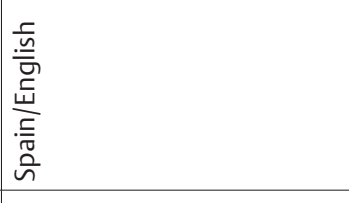 & 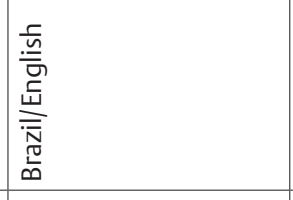 & 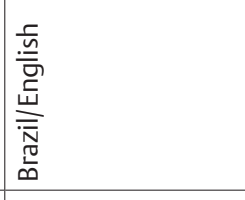 \\
\hline 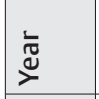 & $\stackrel{\infty}{\stackrel{N}{N}}$ & $\stackrel{i}{\stackrel{i}{N}}$ & 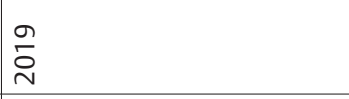 & $\stackrel{\sim}{\stackrel{N}{N}}$ & $\stackrel{\text { Ln }}{\stackrel{2}{\sim}}$ \\
\hline 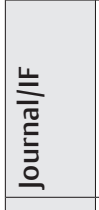 & 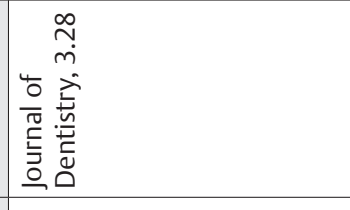 & 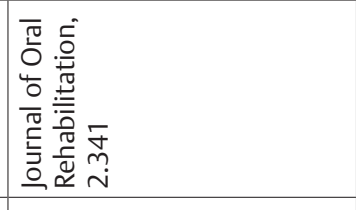 & 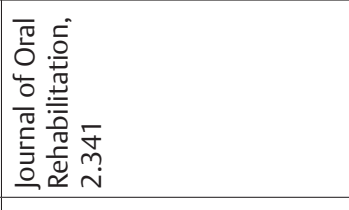 & 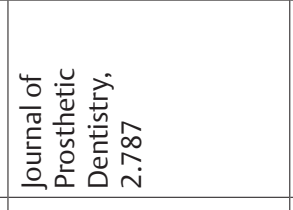 & 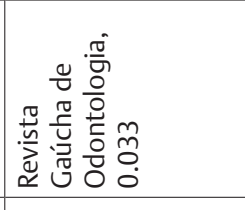 \\
\hline 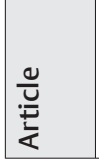 & 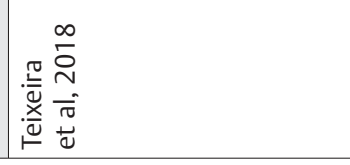 & 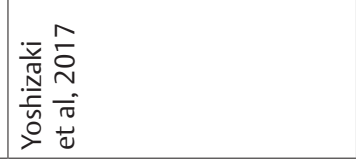 & 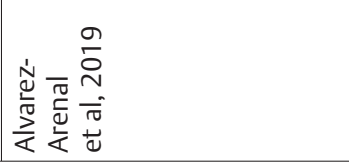 & 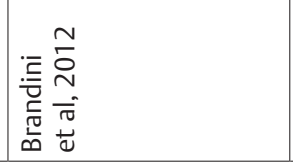 & 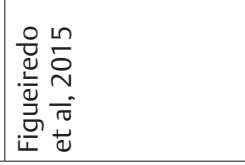 \\
\hline
\end{tabular}


Table 3 Description of included articles in the study (results and conclusion)

\begin{tabular}{|c|c|c|}
\hline Article & Relevant results to the study & Conclusion \\
\hline $\begin{array}{l}\text { Brandini } \\
\text { et al, } 2012\end{array}$ & $\begin{array}{l}46 \text { patients with NCCL ( } 171 \text { teeth with lesions) } \\
\text { Of } 1,296 \text { teeth examined: } \\
\text { - NCCL: } 171 \\
\text { Teeth with NCCL and maxillary position when occlusal trauma occurs: } \\
\text { - MIP: } n=61 ; p \text {-value } \leq 0.001 \\
\text { - Centric relation: } n=59 ; p \text {-value } \leq 0.001 \\
\text { - Working side: } n=80 ; p \text {-value } \leq 0.001 \\
\text { - Nonworking side: } n=24 ; p \text {-value } \leq 0.001 \\
\text { - Protrusion: } n=14 ; p \text {-value }=0.002\end{array}$ & $\begin{array}{l}\text { Although the etiology of NCCL is } \\
\text { multifactorial, the results of this } \\
\text { study indicate that the direction and } \\
\text { intensity of forces applied to teeth are } \\
\text { important contributions to the occur- } \\
\text { rence of NCCL }\end{array}$ \\
\hline $\begin{array}{l}\text { Figueiredo } \\
\text { et al, } 2015\end{array}$ & 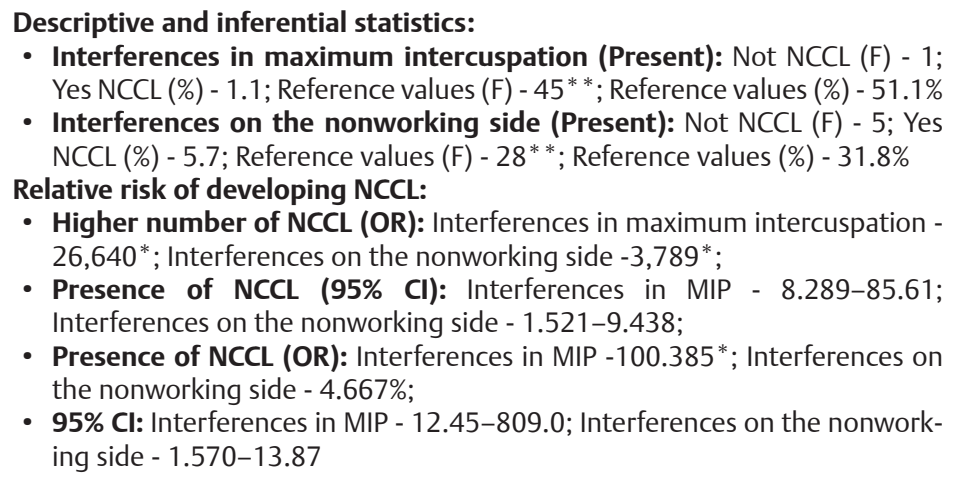 & $\begin{array}{l}\text { Occlusal interference in maximum } \\
\text { intercuspation and on the nonworking } \\
\text { side are risk factors for a greater num- } \\
\text { ber of injuries and their development }\end{array}$ \\
\hline $\begin{array}{l}\text { Yoshizaki } \\
\text { et al, } 2017\end{array}$ & $\begin{array}{l}80 \text { patients with } \mathrm{NCCL} \\
\text { Of } 2,902 \text { teeth examined: } \\
\text { - NCCL }-280 \\
\text { Poisson analysis of the association between independent variables and } \\
\text { the presence of } \mathrm{NCCL} \text { : } \\
\text { Premature contacts: } \\
\text { MIP: } \text { Adjusted prevalence ratio }=3.68 ; 95 \% \mathrm{Cl}=2.43-5.59 ; p \text {-value } \leq 0.0001 \\
\text { Nonworking side: } \text { Adjusted prevalence ratio }=2.76 ; 95 \% \mathrm{Cl}=1.27-5.99 ; \\
p \text {-value } \leq 0.010\end{array}$ & $\begin{array}{l}\text { Factors associated with NCCL were } \\
\text { - Age; } \\
\text { - Presence of interferences at max- } \\
\text { imum intercuspation and on the } \\
\text { nonworking side; } \\
\text { - Consumption of wine and alcoholic } \\
\text { beverages }\end{array}$ \\
\hline $\begin{array}{l}\text { Teixeira } \\
\text { et al, } 2018\end{array}$ & $\begin{array}{l}163 \text { patients with } \mathrm{NCCL} \\
110 \text { patients with } \mathrm{RG} \\
\text { Of } \mathbf{5 , 1 8 0} \text { teeth examined: } \\
\text { - NCCL }-1,308 \\
\text { - } \mathrm{GR}-1,334 \\
\text { - NCCL, GR, and CDH - } 479 \\
\text { Bivariate analysis: } \\
\text { Premature contacts (Yes): } \\
\text { - NCCL - Mean }=7.42 ; \mathrm{SE}=0.42 ; p \text {-value }=0.008 \\
\text { - } \mathrm{GR}-\text { Mean }=7.68 ; \mathrm{SE}=0.54 ; p \text {-value }=0.008 \\
\text { Multivariate analysis: } \\
\text { Premature contacts (Yes): } \\
\text { - NCCL - Estimate }=2.999 ; 95 \% \mathrm{Cl}=0.774-5.223 ; p \text {-value }=0.009 \\
\text { - GR - Estimate }=3.956 ; 95 \% \mathrm{Cl}=1.072-6.840 ; p \text {-value }=0.007\end{array}$ & $\begin{array}{l}\text { - Confirms, within limitations, that } \\
\text { NCCL and GR increase with age; } \\
\text { - NCCL, CDH, and GR have a positive } \\
\text { correlation; } \\
\text { - Lesion depth and morphology } \\
\text { contribute to different levels of } \\
\text { recession; } \\
\text { - Age, gender, gastric diseases, and } \\
\text { occlusal trauma were relevant fac- } \\
\text { tors for the occurrence of NCCL, } \\
\text { CDH, and GR }\end{array}$ \\
\hline $\begin{array}{l}\text { Alvarez-Arenal } \\
\text { et al, } 2019\end{array}$ & 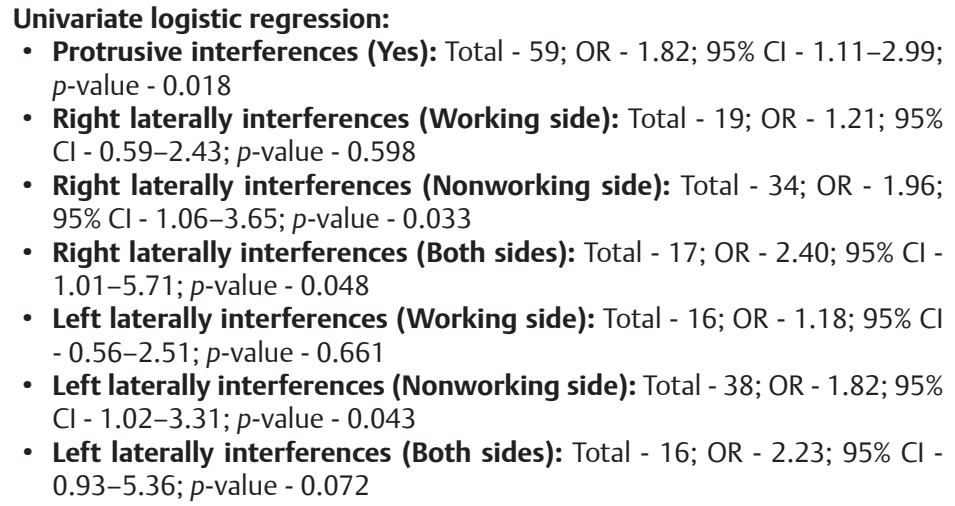 & $\begin{array}{l}\text { - NCCL probably have a multifactorial } \\
\text { etiology; } \\
\text { - The risk factors contained in this } \\
\text { predictive model are not enough to } \\
\text { explain the presence of NCCL; } \\
\text { - Protrusive and nonworking side } \\
\text { interferences are significant for the } \\
\text { occurrence of NCCL, in univariate or } \\
\text { isolated analysis, but not in multi- } \\
\text { variate analysis }\end{array}$ \\
\hline
\end{tabular}

Abbreviations: $\mathrm{CDH}$, cervical dentin hypersensitivity; $\mathrm{Cl}$, confidence interval; $\mathrm{GR}$, gingival recession; MIP, maximum intercuspation position; NCCL, noncarious cervical lesion; OR, odds ratio; SE, standard error.

${ }^{*} p<0.05$

${ }^{* *} p<0.01$ 


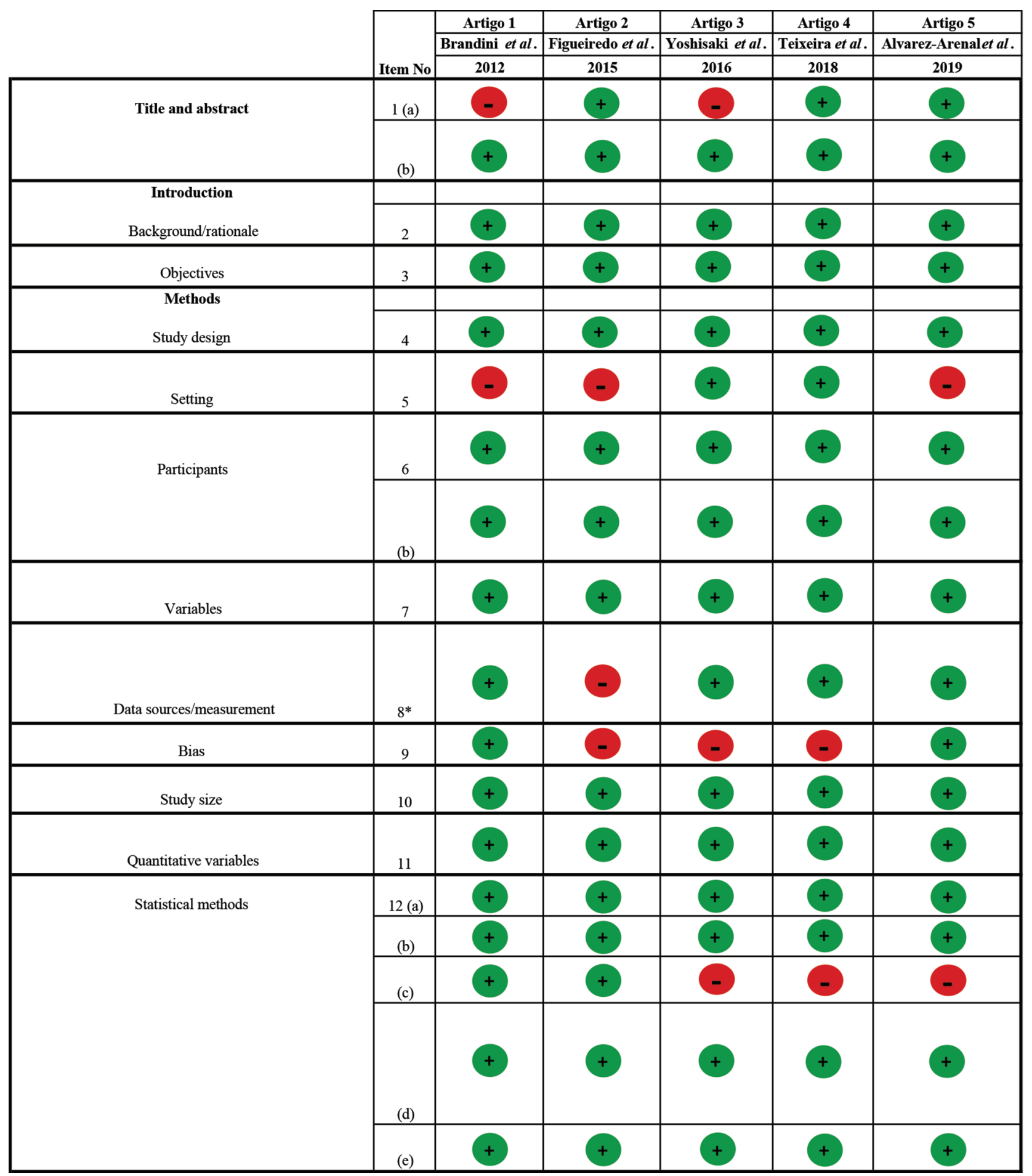

Fig. 2 Quality of assessment; Strengthening the Reporting of Observational Studies in Epidemiology (STROBE).

NCCL. As for the study developed by Alvarez-Arenal et al, ${ }^{34}$ interferences during protrusive movements and on the nonwork side were statistically significant when the univariate analysis was conducted, but not in the multivariate analysis. Brandini et $\mathrm{al}^{35}$ also concluded, more generally, that the direction and intensity of forces, due to occlusal trauma, is an important factor for the occurrence of NCCL. Teixeira et $\mathrm{al}^{31}$ were not objective in the conclusion, reporting several factors, including occlusal trauma, associated with the development of both NCCL and GR, not specifying whether it was related to both or just one of the types of injuries, although it was verified in both, with presence of statistical significances $(p<0.05)$.

The occlusal scheme with the development of NCCL was studied only by Brandini et al..$^{35} \mathrm{~A}$ positive association was obtained between the occurrence of NCCL and the presence of group function during left (63\%) and right (54\%) laterality movements. 


\section{NCCL and GR Location and Etiology}

The analysis of the role of occlusal trauma as an etiological factor in the presence of $\mathrm{NCCL}^{31-35}$ and $\mathrm{GR}^{31}$ was performed in all the studies. NCCL location was not performed by one study, Alvarez-Arenal et al. ${ }^{34}$ The GR preferential location also was not studied by Teixeira et al, ${ }^{31}$ although it was the only study that focused on the relationship between occlusal trauma and the occurrence of GR.

After analysis, it was concluded in three articles ${ }^{31,32,35}$ that NCCLs were more prevalent in the maxillary premolars. Yoshizaki et $\mathrm{a}^{32}$ had $57 \%$ of incidence in premolars, while Brandini et $\mathrm{al}^{35}$ detailed this issue, affirming more presence in first premolars $(23.1 \%$ of the total NCCL on the right side and $20 \%$ at maxillary on the left side). Teixeira et $\mathrm{al}^{31}$ and Figueiredo et $\mathrm{a}^{33}$ concluded that this type of lesions appeared exponentially in maxillary premolars.

\section{Nonocclusal Factors Causing NCCL and GR}

Abrasive/traumatic brushing, ${ }^{31,32,34}$ extrinsic or intrinsic ${ }^{31}$ acid activity, ${ }^{31,32,34}$ and parafunctional habits ${ }^{31,33,34}$ were reported in the articles and included as etiological causal factor of NCCL and GR. The abrasive/traumatic brushing had contradictory results and did not present a statistical significance, ${ }^{31,32}$ but it can be considered a contributing factor. Only one study $^{34}$ considered it as a risk factor for NCCL.

Another variable reported was the acidic activity and its influence on the development of NCCL. It is worth to be noted that a positive correlation associated with the presence of gastroesophageal diseases but not significant $(p>0.05)$. Similarly, a relationship was found between the consumption of alcoholic beverages and consumption of exogenous acid with the occurrence of NCCL.

Parafunctional habits have been suggested as a factor that can play a major role in the development of NCCL. ${ }^{37,38}$ A positive correlation between the existence of parafunctional habits and NCCL occurrence was observed in two studies. ${ }^{33,34}$ On the other hand, one study ${ }^{31}$ did not verify statistically significant correlation between occlusal parafunction and NCCL/GR.

\section{Discussion}

The role of occlusal trauma in the etiology of GR and NCCL is a topic of clinical relevance in dentistry. However, it remains a controversial subject due to the reduced current scientific evidence that supports its true relation.

\section{Studies Quality}

It is noteworthy that, from the elected studies, all are in the middle of the pyramid of quality of scientific evidence. ${ }^{42}$ STROBE Statement was used to assess the quality and risk of bias, which all achieved a high-quality classification. Despite, Alvarez-Arenal et al study ${ }^{34}$ presented a somewhat compromising detail of the quality of the study.

Study Design, Population Characteristics, and Etiology Regarding patients age, three studies ${ }^{31,32,35}$ had a reduced average age (39-41 years). So, the premise that the prevalence of
NCCLs and GR increases with age becomes limited considering this aspect, particularly in the Brandini et al study. ${ }^{35}$ Yoshizaki et $\mathrm{al}^{32}$ found a higher prevalence in patients aged 31 to 50 years, and another study ${ }^{34}$ had no conclusion regarding age. Only Teixeira et al ${ }^{13}$ reported an association between age and GR, also it was the only study included to evaluate GR. It was suggested by two studies ${ }^{31,32}$ that age is an etiological factor due to the longer exposure to which an older individual is subjected, corroborating the information available in the study developed by Borcic et al. ${ }^{42}$

For clinical diagnosis performed, if single or six uncalibrated examiners, there was a risk of bias and imprecision of the studies may increase, jeopardizing also the reproducibility. Also, no laboratory study was included in this SR, given the inherent limitations of finite element analysis (based on computer models, not completely representing teeth in vivo; most of the studies regarding NCCLs use two-dimensional models). ${ }^{39-41}$

It is safe to say that NCCL occurred preferentially in upper premolars, which revealed to be in agreement with other previous studies. ${ }^{19,35,42,43}$ This prevalence is verified probably due to the lower capacity to absorb lateral forces observed in premolars when compared with canines, leading to cervical tension and a consequent occurrence of NCCL. ${ }^{44}$

Three studies ${ }^{31,33,34}$ tested this etiological factor (parafunctional habits) and in two ${ }^{33,34}$ had a positive correlation with NCCL occurrence, despite being low. ${ }^{33}$ On the other hand, Teixeira et al ${ }^{31}$ could not verify a significant correlation with NCCL or GR, suggesting it as an enhancer of tooth loss at a cervical level, when compared with physiological forces $^{37,38}$ since the magnitude of forces during this type of habit greatly exceed loads during normal activity. ${ }^{31}$

The acidic activity was another factor analyzed by three articles ${ }^{31,32,34}$ with no unanimous results, and was considered a contributing factor for the occurrence of NCCL but not GR. Also, the role that abrasive/traumatic brushing played in the development of both NCCL and GR, three studies ${ }^{31,32,34}$ considered it, nevertheless, in this SR the data verified was not enough to draw any conclusions about this topic. Regarding brushing, it is important to state that two studies 45,46 described the existence of NCCL in populations that did not have brushing habits, in concordance with Teixeira et $\mathrm{al}^{31}$ and an in vitro study ${ }^{47}$ which has shown that the presence of this factor is not enough for the development of these NCCLs. On the other hand, Morigami et $\mathrm{a}^{48}$ reported higher occurrence of this lesion in the left hemi-arch in right-handed patients, suggesting the influence of the brushing method on the etiology of NCCL.

Then, the evidences presented here are in concordance with Fan and Caton ${ }^{5}$ study and are weak and not feasible to conclude occlusal trauma causes periodontal alterations. Conversely, a case report published by Ustun et $\mathrm{al}^{7}$ affirmed, in a patient Angle Class III malocclusion and with deep bite, that the severe GR was occasioned by the traumatic occlusion, which is in agreement with Jati et $\mathrm{a}^{49}$ who demonstrated bone dehiscence and V-shaped recession due to occlusal trauma. Therefore, Campos et $\mathrm{al}^{50}$ in an experimental study, 
concluded that occlusal trauma promoted bone resorption after 14 days of analyses, while it did not cause GR.

Within the limitation of this SR, it can be concluded that few studies were published in the past 10 years, highlighting that NCCL and GR present a multifactorial etiology. However, the traumatic occlusion with consequent exacerbated forces to which the teeth are subjected seem to be associated with the occurrence of NCCL. No conclusions regarding the association of GR with the presence of occlusal trauma were possible to be done. The few published studies showed a high degree of heterogeneity, which suggests new well-designed randomized controlled clinical studies on the subject.

\section{Conflict of Interest}

The authors declare no conflicts of interest with this study.

\section{References}

1 Wennström JL. Mucogingival therapy. Ann Periodontol 1996;1(1):671-701

2 Camargo PM, Melnick PR, Kenney EB. The use of free gingival grafts for aesthetic purposes. Periodontol 2000 2001;27:72-96

3 Chambrone L, Chambrone LA. Gingival recessions caused by lip piercing: case report. J Can Dent Assoc 2003;69(8):505-508

4 Carranza F, Klokkevold P, Takei H, Newman M, Carranza's Clinical Periodontology. 13th edition. Philadelphia: Elsevier Saunders; 2019

5 Fan J, Caton JG. Occlusal trauma and excessive occlusal forces: narrative review, case definitions, and diagnostic considerations. J Clin Periodontol 2018;45(Suppl 20):S199-S206

6 Steffens J, Marcantonio R. Classificação das Doenças e Condições Periodontais e Peri-implantares 2018: guia Prático e Pontos-Chave. Rev Odontol UNESP 2018;47(4):189-197

7 Ustun K, Sari Z, Orucoglu H, Duran I, Hakki SS. Severe gingival recession caused by traumatic occlusion and mucogingival stress: a case report. Eur J Dent 2008;2(2):127-133

8 Merijohn GK. Management and prevention of gingival recession. Periodontol 2000 2016;71(1):228-242

9 Kundapur PP, Bhat KM, Bhat GS. Association of trauma from occlusion with localized gingival recession in mandibular anterior teeth. Dent Res J (Isfahan 2009;6(2):71-74

10 Passanezi E, Sant'Ana ACP. Role of occlusion in periodontal disease. Periodontol 2000 2019;79(1):129-150

11 Zucchelli G, Mounssif I. Periodontal plastic surgery. Periodontol 2000 2015;68(1):333-368

12 Krishna Prasad D, Sridhar Shetty N, Solomon EG. The influence of occlusal trauma on gingival recession and gingival clefts. J Indian Prosthodont Soc 2013;13(1):7-12

13 Machado NA, Henriques JC, Lelis ER. Tavares M, Almeida Gde A, Fernandes Neto AJ. Identification of occlusal prematurity by clinical examination and cone-beam computed tomography. Braz Dent J 2013;24(1):64-67

14 Okeson J. Tratamiento de Oclusión y Afecciones Temporomandibulares. 7th edition. Barcelona: Elsevier Saunders; 2013

15 Dawson P, Oclusão funcional: da ATM ao desenho do sorriso. Brasil: Quintesse Editora Lda; 2019

16 Houston W, Stephens C, Tulley W, The scope of orthodontic practice. In: Wright J, ed. A Textbook of Orthodontics. 2nd edition. London, UK: Elsevier-Health Sciences Division; 1992 $1-13$

17 Pihlstrom BL, Anderson KA, Aeppli D, Schaffer EM. Association between signs of trauma from occlusion and periodontitis. J Periodontol 1986;57(1):1-6
18 Miller PD Jr. A classification of marginal tissue recession. Int J Periodontics Restorative Dent 1985;5(2):8-13

19 Bartlett DW, Shah P. A critical review of non-carious cervical (wear) lesions and the role of abfraction, erosion, and abrasion. J Dent Res 2006;85(4):306-312

20 Grippo JO. Abfractions: a new classification of hard tissue lesions of teeth. J Esthet Dent 1991;3(1):14-19

21 Senna P, Del Bel Cury A, Rösing C. Non-carious cervical lesions and occlusion: a systematic review of clinical studies. J Oral Rehabil 2012;39(6):450-462

22 Wood ID, Kassir AS, Brunton PA. Effect of lateral excursive movements on the progression of abfraction lesions. Oper Dent 2009;34(3):273-279

23 Lee WC, Eakle WS. Possible role of tensile stress in the etiology of cervical erosive lesions of teeth. J Prosthet Dent 1984;52(3):374-380

24 Duangthip D, Man A, Poon PH, Lo ECM, Chu CH. Occlusal stress is involved in the formation of non-carious cervical lesions. A systematic review of abfraction. Am J Dent 2017;30(4):212-220

25 Bernhardt O, Gesch D, Schwahn C, et al. Epidemiological evaluation of the multifactorial aetiology of abfractions. J Oral Rehabil 2006;33(1):17-25

26 Ommerborn MA, Schneider C, Giraki M, et al. In vivo evaluation of noncarious cervical lesions in sleep bruxism subjects. J Prosthet Dent 2007;98(2):150-158

27 Tsiggos N, Tortopidis D, Hatzikyriakos A, Menexes G. Association between self-reported bruxism activity and occurrence of dental attrition, abfraction, and occlusal pits on natural teeth. J Prosthet Dent 2008;100(1):41-46

28 Telles D, Pegoraro LF, Pereira JC. Incidence of noncarious cervical lesions and their relation to the presence of wear facets. J Esthet Restor Dent 2006;18(4):178-183, discussion 184

29 Michael JA, Townsend GC, Greenwood LF, Kaidonis JA. Abfraction: separating fact from fiction. Aust Dent J 2009;54(1):2-8

30 Moher D, Liberati A, Tetzlaff J, Altman DG; PRISMA Group. Preferred reporting items for systematic reviews and meta-analyses: the PRISMA statement. Ann Intern Med 2009;151(4):264-269, W64

31 Teixeira DNR, Zeola LF, Machado AC, et al. Relationship between noncarious cervical lesions, cervical dentin hypersensitivity, gingival recession, and associated risk factors: a cross-sectional study. J Dent 2018;76:93-97

32 Yoshizaki KT, Francisconi-Dos-Rios LF, Sobral MA, Aranha AC Mendes FM, Scaramucci T. Clinical features and factors associated with non-carious cervical lesions and dentin hypersensitivity. J Oral Rehabil 2017;44(2):112-118

33 Figueiredo VM, Santos RL, Batista AU. Noncarious cervical lesions in occlusion service patients: occlusal aspects and risk factors. Rev Gaucha Odontol 2015;63(4):389-396

34 Alvarez-Arenal A, Alvarez-Menendez L, Gonzalez-Gonzalez I, Alvarez-Riesgo JA, Brizuela-Velasco A, deLlanos-Lanchares $\mathrm{H}$. Non-carious cervical lesions and risk factors: a case-control study. J Oral Rehabil 2019;46(1):65-75

35 Brandini DA, Trevisan CL, Panzarini SR, Pedrini D. Clinical evaluation of the association between noncarious cervical lesions and occlusal forces. J Prosthet Dent 2012;108(5):298-303

36 Sawlani K, Lawson NC, Burgess JO, et al. Factors influencing the progression of noncarious cervical lesions: a 5-year prospective clinical evaluation. J Prosthet Dent 2016;115(5):571-577

37 Grippo JO, Simring M, Coleman TA. Abfraction, abrasion, biocorrosion, and the enigma of noncarious cervical lesions: a 20-year perspective. J Esthet Restor Dent 2012;24(1):10-23

38 Grippo JO, Simring M, Schreiner S. Attrition, abrasion, corrosion and abfraction revisited: a new perspective on tooth surface lesions. J Am Dent Assoc 2004;135(8):1109-1118, quiz $1163-1165$ 
39 Beresescu G, Brezeanu LC. Biomechanics of noncarious cervical lesions. Meditech 2011;36:270-275

40 Bhundia S, Bartlett D, O'Toole S. Non-carious cervical lesions can terminology influence our clinical assessment? Br Dent J 2019;227(11):985-988

41 Stanusi A, Mercut V, Scrieciu M, et al. Effects of occlusal loads in the genesis of non-carious cervical lesions- a finite element study. Roman J Oral Rehabilit 2019;11(1):60-68

42 Borcic J, Anic I, Urek MM, Ferreri S. The prevalence of non-carious cervical lesions in permanent dentition. J Oral Rehabil 2004;31(2):117-123

43 Aw TC, Lepe X, Johnson GH, Mancl L. Characteristics of noncarious cervical lesions: a clinical investigation. J Am Dent Assoc 2002;133(6):725-733

44 Rees JS, Hammadeh M, Jagger DC. Abfraction lesion formation in maxillary incisors, canines and premolars: a finite element study. Eur J Oral Sci 2003;111(2):149-154
45 Smith BG, Knight JK. An index for measuring the wear of teeth. Br Dent J 1984;156(12):435-438

46 Faye B, Kane AW, Sarr M, Lo C, Ritter AV, Grippo JO. Noncarious cervical lesions among a non-toothbrushing population with Hansen's disease (leprosy): initial findings. Quintessence Int 2006;37(8):613-619

47 Dzakovich JJ, Oslak RR. In vitro reproduction of noncarious cervical lesions. J Prosthet Dent 2008;100(1):1-10

48 Morigami M, Uno S, Sugizaki J, Yukisada K, Yamada T. Clinical survey of cervical tooth lesions in first-appointment patients. Chin J Dent Res 2011;14(2):127-133

49 Jati AS, Furquim LZ, Consolaro A. Gingival recession: its causes and types, and the importance of orthodontic treatment. Dental Press J Orthod 2016;21(3):18-29

50 Campos MLG, Tomazi P, Lopes ACT, et al. The influence of primary occlusal trauma on the development of gingival recession. Rev Clin Periodonc Imp Rehab Oral 2016;9(3):271-276 